\title{
Polskie losy biblioteki Tyszkiewiczów z Czerwonego Dworu
}

Biblioteka i archiwum hr. Tyszkiewiczów z Czerwonego Dworu pod Kownem jeszcze na początku XX w. należały do najbogatszych zbiorów rodzinnych na Litwie. Liczyły wówczas 20000 dokumentów, 12000 listów, przeszło 10000 tomów książek, w tym wiele rzadkich starych druków czy wręcz unikatów oraz niezwykły zbiór panegiryków łacińskich i polskich $(\mathrm{XVII}-\mathrm{XVIII} \text { w. })^{1}$. Na bogatą kolekcję składała się ponadto różnorodna galeria obrazów wybitnych malarzy polskich i obcych (m.in. Bernarda Caneletta, Marcella Bacciarellego, Szymona Czechowicza, Walentego Wańkowicza, Jana Rustema). Zarówno pałac w Czerwonym Dworze, jak i biblioteka pozostawały w rękach tej rodziny do wybuchu I wojny światowej.

W książce Lilianny Narkowicz pt. Muzealnicy i kolekcjonerzy czytamy:

Ostatni właściciel majątku, Benedykt Jan Tyszkiewicz (żyjący w latach 1875-1948), wraz z żoną Różą z Branickich (zmarłą w 1953 r.), stale przebywając za granicą, nie żałując na swoje kosztowne hobby (żeglarstwo, fotografia, kolekcjonowanie) i prowadząc bogate życie towarzyskie [...], co jakiś czas, jeszcze przed I wojną światową, pozbywali się swoich kolekcji znajdujących się w zamku na Litwie, jak też gospodarstw leśnych i folwarków [...]. Stąd też większość dzieł sztuki opuściła majątek przed 1915 rokiem. Sporo swoich cennych zbiorów złożonych w kilku należących do nich domach, za pośrednictwem zaufanych służących, uchronili i w obawie przed utratą wszystkiego w okresie międzywojennym trzymali między innymi jako depozyt w Suchej Beskidzkiej².

I wojna światowa zaskoczyła Tyszkiewiczów przebywających wówczas z dziesięcioletnim synem Benedyktem Władysławem (1905-1956) w majątku Stawiszcze na Ukrainie, należącym do rodziny Róży. Kolejne niespokojne lata spędzili oni u bliskich w Kijowie. Tymczasem w Czerwonym Dworze rozmieszczono sztab feldmarszałka Paula Ludwika von Hindenburga, dowódcy

1 Zob. L. Narkowicz, Muzealnicy i kolekcjonerzy. Zbiory rodziny Tyszkiewiczów i ich rola w zaborze rosyjskim, Wrocław 2013, s. 226-228.

2 Tamże, s. 232. 
frontu wschodniego. W 1921 r. zamek przejęło państwo litewskie, a Tyszkiewiczowie już nigdy w nim nie zamieszkali. Stracili oni tym samym kontrolę nad pozostałymi w majątku dobrami. Według inwentarza (sporządzonego $\mathrm{w}$ 1940 r. w Czerwonym Dworze przez sowieckie władze litewskie) z bogatego księgozbioru pozostało zaledwie kilka egzemplarzy, które trafiły następnie do miejscowej biblioteki. Z zeznań okolicznych mieszkańców wynikało, że wszystko zostało rozkradzione przez miejscowych.

Część biblioteki hrabiego B.J. Tyszkiewicza z Czerwonego Dworu opuściła siedzibę rodową już na początku XX w. ${ }^{3} \mathrm{~W}$ tym czasie w obiegu antykwarycznym znalazły się m.in. cenne rękopisy, z których niewielki fragment został zakupiony do zbiorów Biblioteki Narodowej w Warszawie. Prawie na wszystkich pozyskanych przez książnicę dokumentach zachowała się owalna tuszowa pieczątka: Archiwum Czerwonodworskie. Są to głównie materiały dotyczące działalności publicznej z przełomu XVIII i XIX w. ${ }^{4}$ oraz publicystyka polityczna z czasów Stanisława Augusta Poniatowskiego, a także wycinek Archiwum Zabiełłów. Przy porządkowaniu nadano zbiorowi układ chronologiczny. Obecnie materiały zostały wstępnie opracowane i przechowywane są pod następującymi sygnaturami:

- O pojedynkach uwaga, pol., kon. XVIII w., 4 s. Akc. 15324;

- Myśli do prospektu drugiej Ksiegi Praw Stanisława Augusta o winach, zbrodniach i karach, pol., ok. 1780. Akc. 15462;

- Uwagi od Stanu Duchownego podane JW. Andrzejowi Zamoyskiemu Kawalerowi Orderu Orta Białego układać majacemu Prawa Polskie, pol., łac., fr., niem., 16 II 1777 r. Akc. 15476;

- Listy i pisma różnych do różnych, pol., rus., 1621-1813, 190 k. (113 dokumentów i 45 obwolut). Akc. 16165 t. 1-4:

T. 1: Listy i pisma różnych do różnych z lat 1621-1772;

T. 2: Listy i pisma różnych do różnych z lat 1773-1813;

T. 3: Publicystyka czasów stanistawowskich;

T. 4: Obwoluty z notami kolekcjonerów i antykwariuszy ${ }^{5}$.

W pierwszych dekadach XX w. książki z biblioteki czerwonodworskiej notowano także w obiegu prywatnym. Były przedmiotem wymian, darów lub sprzedaży wśród polskich kolekcjonerów. Jednym z przykładów ożywionego ruchu bibliofilskiego z udziałem egzemplarzy czerwonodworskich

3 Na temat losów biblioteki i archiwum rodziny Tyszkiewiczów z Czerwonego Dworu do lat czterdziestych XX w. pisała A. Snitkuvienè: Czerwony Dwór. Grafowie Tyszkiewiczowie i ich spuścizna = Raudondvaris. Grafai Tiškevičai ir ju palikimas, tłum. M. Iwanowicz, Vilnius 1998.

${ }_{4}$ Zob. Zbiory rękopisów $w$ bibliotekach $i$ muzeach $w$ Polsce, oprac. D. Kamolowa przy współudziale T. Sieniatyckiej, Warszawa 2003, s. 364.

5 Dane udostępnione przez Annę Romaniuk, kierownika Zakładu Rękopisów Biblioteki Narodowej. Odpowiedź na kwerendę Wojewódzkiej Biblioteki Publicznej w Olsztynie z dnia 23 XII $2013 \mathrm{r}$. 
mogą być losy Parolotu - niewielkiej, ale cennej, bo niezwykle rzadkiej pozycji wydanej w Kownie w Drukarni Rządowej w 1851 r. Juliusz Wiktor Gomulicki, ostatni ze znanych właścicieli, tak relacjonował w okresie II wojny światowej:

Parolot Żmudzina z rysu swobodnej myśli skreślony ${ }^{[6]}$ autorstwa Antoniego Hryszkiewicza [pozycja nie odnotowana w Bibliografii polskiej Karola Estreichera, zawierająca osobliwy projekt balonu, sterowanego za pomocą machiny parowej - A.R.] dochował się bodaj w dwóch tylko egzemplarzach, z których jeden znajdował się w Kownie, drugi zaś w Czerwonogrodzie, w księgozbiorze Benedykta Tyszkiewicza. Otóż ów egzemplarz czerwonodworski wycyganił od Tyszkiewiczów znany zbieracz wileński Lucjan Uziębło. [Ten zaś wymienił go z Wacławem Gomulickim, ojcem Juliusza - A.R.] Była to niewielka książeczka [zaledwie 56 stron - A.R.] oprawiona w zieloną kompaturkę z wytłoczonym na przedniej stronie napisem PAROLOT, przed kartą tytułową mająca zaś wklejoną kartę dedykacyjną, na której Hryszkiewicz wykaligrafował wierszyk do Tyszkiewicza, mecenasującego jego projektom balonowym. Wacław Gomulicki opatrzył książeczkę swoim monogramem oraz trzema gwiazdkami [oznaczającymi unikat - A.R.] ${ }^{7}$

Po śmierci Wacława Gomulickiego w 1919 r. Parolot wraz z jego księgozbiorem zawędrował do warszawskiej księgarni i antykwarni Aleksandra Heflicha „Światło”, gdzie tom wypatrzył Roman Ziffer, kolejny nabywca. Po jego śmierci książeczka trafiła do Ludomiła Lewenstama, bibliofila i dziennikarza, który dwa lata przed śmiercią w 1942 r. sprzedał ją Juliuszowi W. Gomulickiemu.

Decyzją samego B.J. Tyszkiewicza jeden z najcenniejszych księgozbiorów rodziny zgromadzony na Wschodzie po $1918 \mathrm{r}$. złożono w depozycie czasowym w Suchej Beskidzkiej, w południowo-zachodniej części Polski, w majątku rodu Branickich. Zbiór przewieziono tam wraz z kolekcją Władysława Branickiego, ojca R. Tyszkiewiczowej ${ }^{8}$. Łącznie dostarczony księgozbiór liczył 13 tysięcy dzieł, z czego czerwonodworski - parę tysięcy woluminów. Jak podaje opracowanie Edwarda Chwalewika z 1926 r., była to:

piękna biblioteka (przeszło 10000 tomów), posiadająca moc starych rzadkich druków XV-XVIII w., nawet unikatów, tudzież bogaty dział panegiry-

\footnotetext{
A. Hryszkiewicz, Parolot Żmudzina, z rysu swobodnej myśli ... skreślony, Kowno 1851.

J.W. Gomulicki, „Diabet i zboże”. Ze wspomnień o warszawskich miłośnikach i ratownikach ksiązki w okupacji hitlerowskiej, [w:] Walka o dobra kultury. Warszawa 1939-1945, t. 2, pod red. S. Lorenza, Warszawa 1970, s. 74. W cytowanym fragmencie autor błędnie podaje imię Aleksandra Hryszkiewicza.

8 Zob. B. Bieńkowska, Książka na przestrzeni dziejów, Warszawa 2005, s. 337 (hasło: Biblioteka Branickich).
} 
ków polsko-łacińskich XVII-XVIII w. Księgozbiór szczęśliwie w znacznej części uratowano, wywieziono z Litwy i złożono w depozycie w Suchej ${ }^{9}$.

Dr Józef Seruga, archiwista i historyk książki, od 1931 r. pełniący funkcję kustosza zbiorów suskich, w swoim liście do Karola Badeckiego, historyka literatury, bibliotekoznawcy i badacza dziejów Lwowa, podał, iż w bibliotece w Suchej zdeponowano ponad 3000 tomów biblioteki z Czerwonego Dworu. Korespondencja ta, datowana na 6 lipca 1932 r., obecnie przechowywana jest w Bibliotece Zakładu Narodowego im. Ossolińskich we Wrocławiu (BOssol.) ${ }^{10}$.

Z kolei Urszula Paszkiewicz twierdzi, w oparciu o dane zawarte w oryginalnej kartotece księgozbioru Tyszkiewiczów z Czerwonego Dworu, iż kolekcja w momencie przewiezienia do Suchej liczyła ok. 4700 dzieł ${ }^{11}$. Wspomniana kartoteka trafiła do Polski wraz ze zbiorami biblioteki Tyszkiewiczów i została zarejestrowana jako Katalog księgozbioru Tyszkiewiczów z Czerwonego Dworu. Tytuł inwentarza został nadany po 1918 r., tj. po złożeniu druków XVI-XVIII w. w Suchej. Opisy starych druków były wykonywane najprawdopodobniej do 1914 r. Kartoteka z Czerwonego Dworu (obecnie przechowywana w Zakładzie Starych Druków Biblioteki Narodowej) zamknięta jest w 33 pudłach i nie posiada odrębnej sygnatury. $\mathrm{Na}$ zachowanych kartach katalogowych w lewym górnym narożniku widnieje wytłoczony herb Tyszkiewiczów Leliwa. Na katalog składa się: katalog alfabetyczny poloników XVII-XVIII w. - ok. 4300 dzieł (31 pudeł) oraz katalog alfabetyczny poloników XVI w. - ok. 400 dzieł (dwa pudła). Na odwrocie kart katalogowych podano ołówkiem sygnatury topograficzne biblioteki Tyszkiewiczów w Czerwonym Dworze ${ }^{12}$.

Niepokoje związane ze zbliżającą się w 1939 r. wojną spowodowały, że już w czerwcu i lipcu tego roku J. Seruga na polecenie Juliusza hrabiego Tarnowskiego, kolejnego z właścicieli Suchej ${ }^{13}$, rozpoczął zabezpieczanie

E. Chwalewik, Zbiory polskie. Archiwa, biblioteki, gabinety, galerie, muzea i inne zbiory pamiątek przeszlości $w$ ojczyźnie i na obczyźnie w porzadku alfabetycznym wedlug miejscowości ułożone, t. 1: A-M, Warszawa-Kraków 1926, reprint z 1991 r., s. 57 (hasło: Czerwony Dwór).

10 Zob. H. Małysiak, Biblioteka Branickich i Tarnowskich w Suchej, Bielsko-Biała 1986, s. 79. Zob. też BOssol, rps 13992 II, Korespondencja K. Badeckiego z lat 1907-1940. List J. Serugi do K. Badeckiego z dnia 6 lipca 1932 r. z Bibl. Zakł. Narod. im. Ossolińskich, Wrocław, (8), s. 185-208. Biblioteka w Czerwonym Dworze liczyła ok. 10000 woluminów. J. Seruga pisze, iż w Suchej zdeponowano ponad 3000 tomów tej biblioteki, Mieczysław Woźnowski określa natomiast depozyt na ok. 4000 tomów starych druków od XV do XVIII w. - zob. tenże, Sucha, „Ziemia. Dwutygodnik Krajoznawczy Ilustrowany” 1931, t. 16, nr 3, s. 48.

11 Zob. U. Paszkiewicz, Cathalogus cathalogorum. Inwentarze $i$ katalogi bibliotek z ziem wschodnich Rzeczypospolitej od XVI wieku do 1939 roku. Spis scalony, poprawiony i uzupetniony, t. 1, Warszawa 2015, s. 149.

12 Informacja o katalogu bez sygnatury za: tamże, s. 149, poz. 388.

13 J. Tarnowski przejął zamek i bibliotekę w Suchej po matce w 1932 r. 
najcenniejszych zbiorów (inkunabułów, rękopisów i grafik oraz archiwum). W momencie wybuchu II wojny światowej część biblioteki została ewakuowana w głąb kraju, zaś sami Tarnowscy wyjechali do Francji. Niemcy wkroczyli do Suchej w pierwszych dniach września 1939 r. - zamek zajęli na kwaterę wojsk oraz mieszkania urzędników niemieckich. W monografii Biblioteka Branickich i Tarnowskich w Suchej Helena Małysiak pisze:

Zbiory biblioteczne pozostawione w Suchej znalazły się na łasce hitlerowców. Przeprowadzana przez Niemców w okresie okupacji planowa grabież polskich dóbr kultury spowodowała konfiskatę i wywóz z zamku suskiego dużej ilości zabytkowych przedmiotów, rzeźb i obrazów. Z biblioteki, która przed wojną przekraczała 100000 woluminów, utworzyli Niemcy placówkę filialną Bibliothek des Zentralinstituts fur Oberschlesiche Landesforschung. Zabezpieczyło to zbiory przed całkowitym zniszczeniem, lecz nie uchroniło od rabunków indywidualnych zbieraczy zabytkowych okazów, a także selekcji, której poddana została literatura polska i Polski dotycząca. Efektem tej selekcji był wywóz znacznej ilości zbiorów na przemiał w żywieckiej fabryce papieru ${ }^{14}$.

Jeszcze pod koniec lat osiemdziesiątych XX w. okupacyjne losy biblioteki i księgozbioru z Suchej nie były szczegółowo zbadane. Zdaniem H. Małysiak informacje były skąpe i wymagały dalszych analiz dokumentacji niemieckiej oraz zebrania relacji i wspomnień od osób mających związek z biblioteką w czasie II wojny światowej ${ }^{15}$.

Po zakończeniu działań wojennych w 1945 r. ruszyła akcja zabezpieczania ocalałych księgozbiorów, mająca na celu ochronę przed ich niszczeniem i rozgrabieniem. W działaniach tych uczestniczyła również Śląska Biblioteka Publiczna w Katowicach, która, jak podaje Franciszek Szymiczek, „od lutego do sierpnia 1946 r. zabezpieczyła ok. 18000 tomów poniemieckich dzieł naukowych"16. Ryszard Nowicki dodaje, iż największą partię zbiorów zwartych, zabezpieczonych przez tę placówkę stanowiła Biblioteka Górnośląska (Oberschlesische Landesbibliothek) w Bytomiu, obejmująca 67000 tomów bez dubletów ${ }^{17}$.

14 H. Małysiak, dz. cyt., s. 90. Warto zaznaczyć, iż na księgozbiór zgromadzony w Bibliothek des Zentralinstituts fur Oberschlesiche Landesforschung składały się dzieła, często o dużej wartości, skonfiskowane także z innych polskich bibliotek rodowych. Na temat tych kolekcji, w tym zbiorów Branickich-Tarnowskich z Suchej, oraz zabezpieczania tych księgozbiorów w pierwszych latach powojennych zob. szerzej: R. Nowicki, Zabezpieczanie księgozbiorów po II wojnie światowej w Polsce, ,Napis” 2005, ser. 11, s. 278.

15 Zob. H. Małysiak, dz. cyt., s. 91.

16 F. Szymiczek, Akcja zabezpieczająca i rewindykacja na Śląsku, „Bibliotekarz” 1946, nr 5, s. 118 - cyt. za R. Nowicki, Zabezpieczanie księgozbiorów po II wojnie..., s. 286.

17 Zob. tamże 
W pierwszych latach powojennych złączone zbiory biblioteki Tarnowskich i Tyszkiewiczów z Suchej w wyniku decyzji Naczelnej Dyrekcji Bibliotek Ministerstwa Oświaty zostały rozproszone ${ }^{18}$. W kilku etapach włączano je do Zbiornicy Księgozbiorów Zabezpieczonych funkcjonującej przy Bibliotece Jagiellońskiej w Krakowie. Ostatnia część zbiorów odszukanych na terenie Śląska dotarła do Krakowa w maju 1949 r. ${ }^{19}$, a 12 lipca 1948 r. F. Szymiczek, ówczesny kierownik Zbiornicy Księgozbiorów Zabezpieczonych w Katowicach, przekazując K. Badeckiemu, kierownikowi Zbiornicy w Krakowie, 2280 tomów z biblioteki suskiej, uznał sprawę tych księgozbiorów za zakończoną ${ }^{20}$. Według szczegółowych informacji podanych przez R. Nowickiego:

W krakowskiej Zbiornicy zdecydowanie przeważały dzieła poniemieckie, ale występowały także rodzime, w tym polskie księgozbiory historyczne. Przykładowo w lipcu 1948 r. segregowano pozostałości księgozbiorów Tarnowskich z Suchej i Tyszkiewiczów z Czerwonego Dworu. Zostały one przywiezione do Biblioteki Jagiellońskiej z Cieszyna, Katowic i Bytomia. [W zbiorze z Czerwonego Dworu - A.R.] rozpoznano jeden inkunabuł, 165 woluminów z XVI w., 768 woluminów z XVII w. oraz 1249 woluminów z XVIII w. [...] W tym też czasie, tj. w lipcu, zostały uporządkowane alfabetycznie katalogi kartkowe księgozbiorów: Tarnowskich z Dzikowa, Lubomirskich z Przeworska, Tarnowskich z Suchej, Tyszkiewiczów z Czerwonego Dworu oraz Potockich z Krzeszowic ${ }^{21}$.

Niemniej jeszcze w listopadzie 1948 r. F. Szymiczek w sprawozdaniach Zbiornicy katowickiej odnotował przekazanie 33 tomów ze zbioru suskiego do Zbiornicy w Krakowie ${ }^{22}$.

18 BJ, rps 7795 III, 7796 III [Karol Badecki]. Zob. też AAN, sygn. 6952, k. 4, Ministerstwo Oświaty. Naczelna Dyrekcja Bibliotek. Wydział Bibliotek Naukowych. Zbiornica Księgozbiorów Zabezpieczonych w Krakowie. Sprawozdania z działalności 1948-49, [Karol Badecki], IX Sprawozdanie Kierownictwa księgozbiorów Zabezpieczonych w Krakowie, Kraków 25 sierpnia 1948 r. - cyt. za R. Nowicki, Zbiory specjalne w zbiornicach księgozbiorów zabezpieczonych. Przyczynek do odbudowy bibliotek i bibliotekarstwa polskiego, [w:] Zbiory specjalne w bibliotekach polskich. Problematyka badawcza i organizacyjna, pod red. A. Borysowskiej, Szczecin 2015, s. 225, przyp. 50.

19 BN O-AZ BN, sygn. 250/12, k. 11, Zastępca Dyrektora Biblioteki Narodowej ds. Ochrony i Udostępniania Zbiorów - Franciszek Szymiczek, Zbiornica Księgozbiorów Zabezpieczonych w Stalinogrodzie 1947-1955 [Katowice, 17 grudnia 1955 r.] - zob. R. Nowicki, Rola katowickiej Zbiornicy Księgozbiorów Zabezpieczonych w powojennej ochronie zbiorów bibliotecznych w Polsce, Bydgoszcz 2015, s. 193, przyp. 755.

20 ABJ, Archiwum Delegata Ministerstwa Oświaty do zabezpieczania księgozbiorów opuszczonych i porzuconych. Sprawozdania, akta i inwentarze dotyczące Kierownictwa [Karola Badeckiego] księgozbiorów zabezpieczonych przez Ministerstwo Oświaty w Bibliotece Jagiellońskiej 1946-1949 - Karol Badecki Potwierdzenie odbioru, Kraków, 12 lipca 1948 r. - zob. R. Nowicki, Rola katowickiej Zbiornicy..., s. 193, przyp. 755.

21 Cyt. za: R. Nowicki, Zbiory specjalne w zbiornicach..., s. 225.

22 AAN, MO NDB, sygn. 6948, k. 19, Wydział Bibliotek Naukowych [Zbiornica Księgozbiorów Zabezpieczonych w Katowicach. Sprawozdania miesięczne z działalności za 1948 r.] - Franciszek Szymiczek. Sprawozdanie rzeczowe Zbiornicy Księgozbiorów Zabezpieczonych za listopad 1948 r., Katowice, 4 grudnia 1948 r. - zob. R. Nowicki, Rola katowickiej Zbiornicy..., s. 193, przyp. 758. 
W wyniku dalszych decyzji Ministerstwa Oświaty księgozbiór z Suchej rozdzielono także pomiędzy Bibliotekę Miejską w Gdańsku i Bibliotekę Zakładu Narodowego im. Ossolińskich we Wrocławiu. Biblioteka Miejska w Gdańsku przejęła ze Zbiornicy Księgozbiorów Zabezpieczonych w Krakowie ponad 5000 dzieł w 8000 wol. ${ }^{23}$ Według informacji otrzymanych od A. Balińskiego z Działu Druków XIX i pierwszej poł. XX w. PAN Biblioteki Gdańskiej wśród woluminów nie było książek z biblioteki z Czerwonego Dworu ${ }^{24}$. Decyzja Ministerstwa Oświaty o przekazaniu Bibliotece Zakładu Narodowego im. Ossolińskich we Wrocławiu starodruków i części druków nowych z Suchej w formie państwowego depozytu zapadła pod koniec 1948 r. Dyrekcję Ossolineum poinformowano o tym w oficjalnym piśmie z 18 listopada 1948 r., przechowywanym obecnie w dziale rękopisów tejże Biblioteki ${ }^{25}$. Franciszek Pajączkowski w swojej publikacji z 1949 r. Zakład Narodowy im. Ossolinskich we Wroctawiu w 1948 roku odnotował:

Dział Starodruków Ossolineum został ogromnie wzbogacony przyznaniem przez Ministerstwo Oświaty zasobu starodruków z b. Biblioteki Tarnowskich z Suchej. Zasób ten wynosi ponad 7000 starodruków, które znajdowały się w Bibliotece Jagiellońskiej w Krakowie ${ }^{26}$.

W tym samym czasie, czyli w 1948 r., ,, z zasobu bibliotek podworskich Ministerstwo Oświaty przyznało Ossolineum równocześnie bibliotekę ordynacką Lubomirskich z Przeworska"27. Informacje te precyzuje H. Małysiak, odwołując się do Katalogu inkunabułów Biblioteki Zakładu im. Ossolinskich we Wrocławiu z 1956 r. Ossolineum otrzymało dokładnie 6899 tomów starodruków, w tym 381 poloników z XVI w. We Wrocławiu znalazły się tym samym dwa inkunabuły, 485 tomów wydawnictw z XVI w., 1568 tomów z XVII w. i 4826 tomów wydawnictw z XVIII w. Ponadto z biblioteki suskiej do zbiorów ossolińskich włączono 5212 tomów druków obcych z XIX i XX w. i 700 woluminów czasopism, w tym 107 tomów czasopism z XVI-XVIII w. Udokumentowana liczba zbiorów z biblioteki Tyszkiewiczów z Czerwonego Dworu to wówczas: 2370 tomów, w tym

23 Zob. H. Małysiak, dz. cyt., s. 91.

24 Odpowiedź PAN Biblioteki Gdańskiej na kwerendę Wojewódzkiej Biblioteki Publicznej w Olsztynie z dnia 10 II 2014 r.

25 BOssol, mps [bez sygn.], Pismo Ministerstwa Oświaty nr NDB/N-5093/48 do Dyrekcji Zakł. Narod. im. Ossolińskich w sprawie przejęcia w depozyt zbiorów Biblioteki Tarnowskich w Suchej z dnia 18 listopada 1948 r. - zob. H. Małysiak, dz. cyt., s. 98, poz. bibl. 50.

26 F. Pajączkowski, Zakład Narodowy im. Ossolińskich we Wrocławiu w 1948 roku, Wrocław 1949, s. 11.

27 Tamże, s. 7. 
jeden tom piętnastowieczny, 165 szesnastowiecznych, 1249 osiemnastowiecznych oraz 187 tomów bez roku wydania ${ }^{28}$.

Jak podaje R. Nowicki, w lutym 1949 r. pozostawało w Bibliotece Jagiellońskiej, jeszcze bez przydziału ok. 12000 dzieł wydanych do 1800 r.: z księgozbioru Tarnowskich z Dzikowa - około 5400 tomów, Potockich z Krzeszowic - około 4000 tomów, Tyszkiewiczów z Czerwonego Dworu - ok. 2600 tomów ${ }^{29}$. Natomiast przejmowanie zbiorów z Suchej przez Ossolineum trwało jeszcze w marcu 1949 r. ${ }^{30}$ Jednak tylko część zbiorów z Suchej trafiła bezpośrednio do Wrocławia. Według dokumentacji z 1948 r. (przechowywanej w Bibliotece Uniwersytetu Adama Mickiewicza w Poznaniu):

do Zbiornicy Księgozbiorów Zabezpieczonych przy Bibliotece Jagiellońskiej w Krakowie (doc. dr Badecki) wysłano część księgozbioru Branickich z Suchej (650 pozycyj). Zbiór powyższy został przekazany Bibliotece U[niwersytetu] P[oznańskiego] przez p. prof. Skubiszewskiego, [a następnie - A.R.] 650 woluminów wywędrowało do Biblioteki Jagiellońskiej ${ }^{31}$.

W książnicy poznańskiej zachował się spis przekazywanych zbiorów, przy czym nie można $\mathrm{w}$ pełni potwierdzić związków tej części kolekcji z biblioteką Tyszkiewiczów. Referaty zabezpieczania i segregacji księgo-

28 Zob. H. Małysiak, dz. cyt., s. 91. Zob. też Katalog inkunabułów Biblioteki Zakładu im. Ossolińskich we Wrocławiu, na podstawie materiałów K. Piekarskiego oprac. A. Kawecka-Gryczowa, Wrocław 1956; BOssol, mps [bez sygn.], Pismo Ministerstwa Oświaty nr NDB/N-5093/48 do Dyrekcji Zakł. Narod. im. Ossolińskich w sprawie przejęcia w depozyt zbiorów Biblioteki Tarnowskich w Suchej z dnia 18 listopada 1948 r. - zob. H. Małysiak, dz. cyt., s. 98 , poz. bibl. 50 .

29 AAN, sygn. 6952, k. 17, Ministerstwo Oświaty. Naczelna Dyrekcja Bibliotek. Wydział Bibliotek Naukowych. Zbiornica Księgozbiorów Zabezpieczonych w Krakowie. Sprawozdania z działalności 1948-49, [Karol Badecki], XII Sprawozdanie Kierownictwa księgozbiorów zabezpieczonych w Krakowie, Kraków 24 lutego 1949 r. - zob. R. Nowicki, Zbiory specjalne w zbiornicach ..., s. 226, przyp. 55.

30 BJ, rps 7796 III T. 2 [Karol Badecki], Spis druków obcych XIX i XX w. oraz czasopism polskich i obcych księgozbioru Tarnowskich z Suchej, przejętych w depozyt przez Bibliotekę Zakładu Narodowego im. Ossolińskich we Wrocławiu z dnia 18 marca 1949 r. - zob. H. Małysiak, dz. cyt., s. 93.

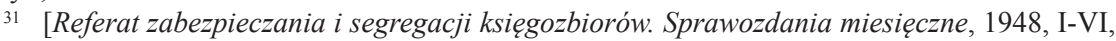
k. 114]; [Referat zabezpieczania i segregacji księgozbiorów. Sprawozdania miesięczne, 1948, X-XI, k. 176-205]; w dwóch teczkach znajduje się spis ponad 600 książek, map i dokumentów przekazanych Bibliotece U.P. przez prof. Skubiszewskiego. Dane według informacji dr. Rafała Wójcika, Kierownika Oddziału Zbiorów Specjalnych Pracowni Starych Druków Biblioteki Uniwersyteckiej Adama Mickiewicza w Poznaniu z dnia 4 stycznia 2014 r. Na temat działalności Zbiornicy Księgozbiorów Zabezpieczonych w Poznaniu, funkcjonującej w pierwszych latach powojennych przy Bibliotece Uniwersyteckiej w Poznaniu, pisze R. Nowicki, Likwidacja Zbiornicy Księgozbiorów Zabezpieczonych w Poznaniu, „Biblioteka” 2014, nr 18, s. 123-134. 


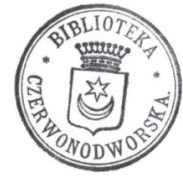

Fot. 1. Pieczęć rodu Tyszkiewiczów z Czerwonego Dworu.

Źródło: Raudondvario dvaras. Laiko ženklai $=$ The Raudondvaris castle. The signs of the times. Tom I, autorstwa Zigmasa Kalesinskasa,

Raudondvaris 2012, s. 119.

Zdjęcie: A. Romulewicz

zbiorów z 1948 r. w formie sprawozdań miesięcznych przechowywane są obecnie w Oddziale Zbiorów Specjalnych Pracowni Starych Druków Biblioteki Uniwersyteckiej Adama Mickiewicza w Poznaniu.

Według danych z 2014 r. w zasobach Biblioteki Zakładu Narodowego im. Ossolińskich we Wrocławiu nie ma obecnie druków dziewiętnasto- i dwudziestowiecznych ani

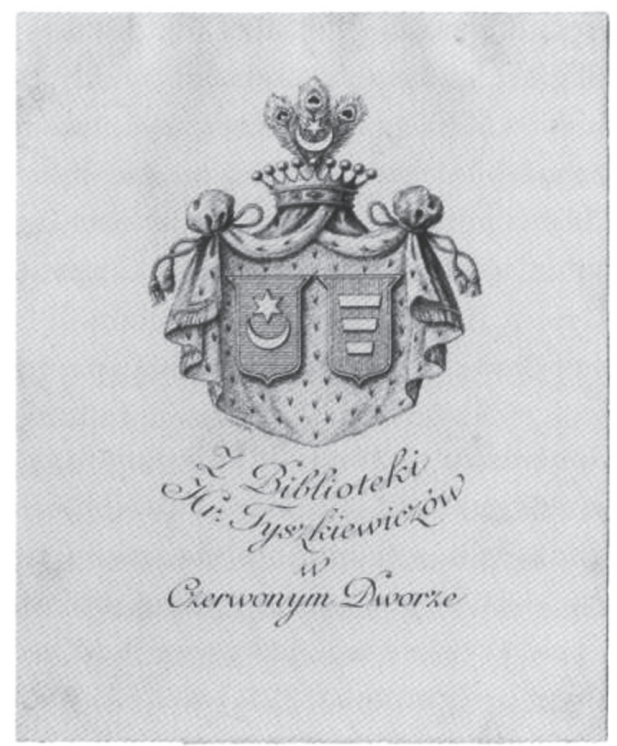

Fot. 2. Ekslibris rodu Tyszkiewiczów z Czerwonego Dworu. Papier. Staloryt. Paryż 1903.

Źródło: Raudondvario dvaras. Laiko ženklai $=$ The Raudondvaris castle.

The signs of the times. Tom I, autorstwa

Zigmasa Kalesinskasa,

Raudondvaris 2012, s. 118.

Zdjęcie: A. Romulewicz rękopisów o proweniencji wskazującej na kolekcję Tyszkiewiczów z Czerwonego Dworu. Znajdują się tam natomiast dwa „luźne” ekslibrisy biblioteki czerwonodworskiej (miedzioryt i metaloryt z początku XX w.), przechowywane w Gabinecie Grafiki Muzeum XX. Lubomirskich, a także niewielki zbiór starych druków: cztery szesnastowieczne, osiem siedemnastowiecznych oraz 19 osiemnastowiecznych ${ }^{32}$. Stan zbiorów pochodzących z biblioteki Tyszkiewiczów w Czerwonym Dworze znajdujących się w zasobach Ossolineum podany 22 stycznia 2014 r. w piśmie do Wojewódzkiej Biblioteki Publicznej (dalej WBP) w Olsztynie potwierdza też Katalog starych druków Biblioteki Zakładu Narodo-

32 [Wykaz zbiorów pochodzących z biblioteki Tyszkiewiczów w Czerwonym Dworze, znajdujących się w zasobach Zakladu Narodowego im. Ossolińskich we Wroctawiu], załącznik do pisma BIN-45/1-14 z dnia 22 stycznia 2014 r. Zakładu Narodowego im. Ossolińskich do Wojewódzkiej Biblioteki Publicznej w Olsztynie. Wykazane zasoby potwierdza zapis w Katalogu starych druków Biblioteki Zaktadu Narodowego im. Ossolińskich. Polnica wieku XVI (z materiałów rejestracyjnych zebranych zespołowo pod kier. K. Zatheya oprac. M. Bohonos), Wrocław 1965. 
wego im. Ossolińskich opracowany przez Marię Bohonos, a wydany w 1965 r. Wszystkie stare druki posiadają znaki proweniencyjne: „Z Biblioteki hr. Tyszkiewiczów w Czerwonym Dworze" (ekslibrisy i pieczęcie).

Ostatnim etapem wędrówki ocalałej części biblioteki z Czerwonego Dworu stała się Warszawa i Biblioteka Narodowa, której kolekcję starych druków po 1945 r. utworzyły fragmenty okaleczonych przez wojnę polskich księgozbiorów historycznych, w tym tzw. podworskich. Z nabytków powojennych Bibliotekę Narodową wyróżniają przekazane jej fragmenty księgozbiorów: Zamoyskich w Warszawie, Tarnowskich z Dzikowa, Potockich z Krzeszowic, Krasińskich w Warszawie oraz Tyszkiewiczów z Czerwonego Dworu ${ }^{33}$. Część z nich to:

nader rzadkie pozycje, często unikatowe druki (głównie z terenu Litwy), [wśród których wiele - A.R.] pochodzi z resztek słynnej biblioteki Joachima Chreptowicza w Szczorsach, założonej w XVIII stuleciu ${ }^{34}$.

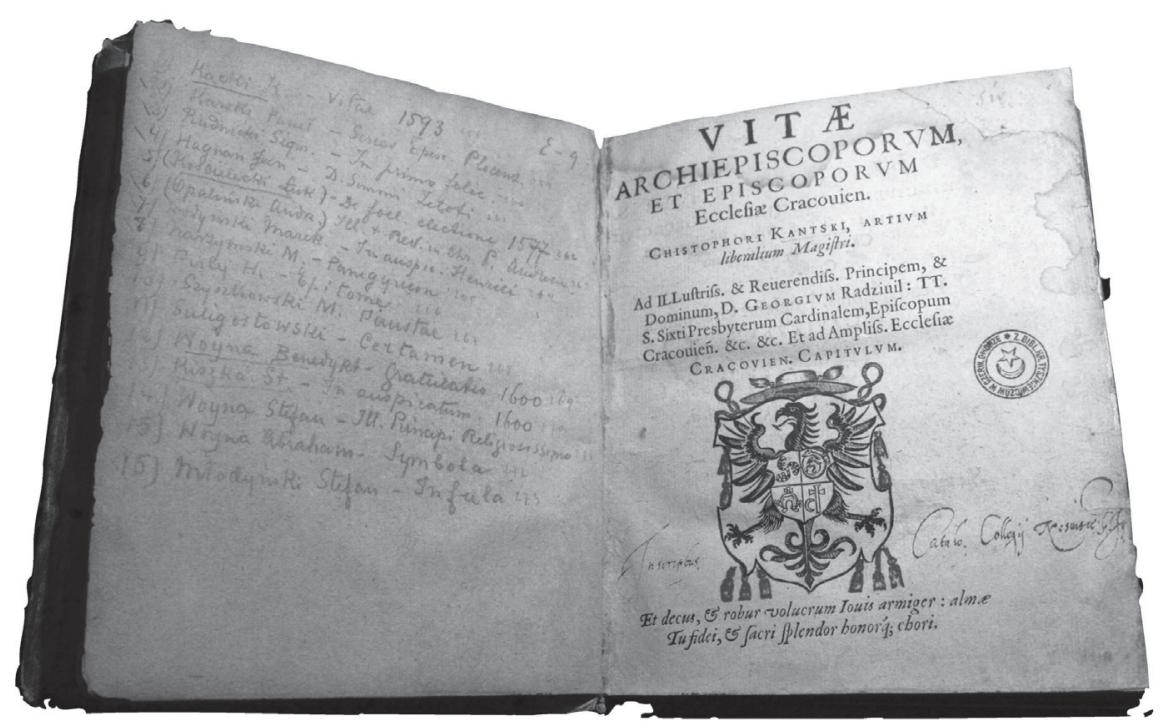

Fot. 3. Pieczęć rodu Tyszkiewiczów z Czerwonego Dworu. Źródło: Vitae archiepiscoporvm et episcoporvm Ecclesiae Cracouien. Christophori Kantski ...

ad ... Georgivm Radziuil. ... cardinalem, episcopum Cracouien[sem] ... et ad ... Ecclesiae Cracovien. capitvlvm ..., Kraków 1593, w zbiorach BN, Sygn.

SD XVI.Qu.417. Zdjęcie: A. Romulewicz

33 Zob. Biblioteka Narodowa w latach 1945-1956, red. B. Horodyski, Warszawa 1958, s. 58.

34 O egzemplarzu obecnie znajdującym się w zbiorach Biblioteki Narodowej w Warszawie (Grzegorz z Żarnowca, Clypeus albo tarcz duchowna z stów Pawła św., 1598, sygn. BN XVI Qu 476), zawierającym ekslibris Joachima Chreptowicza i biblioteki czerwonodworskiej pisała M. Topolska, Czytelnictwo ksiażek wydanych na Litwie i Białorusi w XVI i pierwszej polowie XVII wieku (na podstawie proweniencji starodruków z polskich i zagranicznych bibliotek naukowych), „Pamiętnik Biblioteki Kórnickiej” 1979, T. 15, s. 231. 
Obecnie Biblioteka Narodowa w Warszawie posiada kilka tysięcy dzieł z kolekcji Tyszkiewiczów. Według informacji zamieszczonej na stronie internetowej placówki Biblioteka Tyszkiewiczów z Czerwonego Dworu to ponad 3500 dzieł w prawie 3000 woluminów, z przewagą poloników. Znajduje się w niej „wiele rzadkości bibliograficznych, zwłaszcza druki okolicznościowe związane z Wielkim Księstwem Litewskim"35.

Powyższe dane pozostają szacunkowe i odnoszą się do stanu sprzed 1958 r., w którym kolekcja Tyszkiewiczów z Czerwonego Dworu liczyła dokładnie 3636 dzieł w 2952 wol. ${ }^{36}$ W Bibliotece Narodowej prowadzone są obecnie prace nad omawianym zbiorem mające na celu uaktualnienie danych katalogowych z uwzględnieniem znaków proweniencyjnych. Więk-

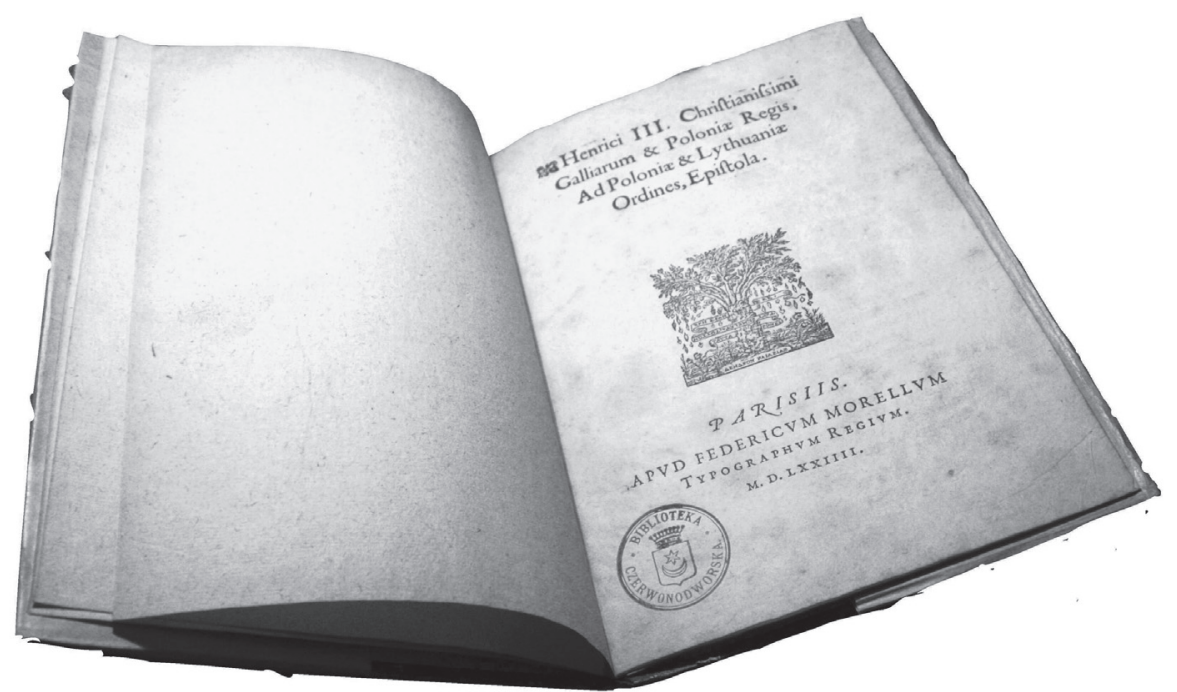

Fot. 4. Pieczęć rodu Tyszkiewiczów z Czerwonego Dworu. Źródło: Henrici III christianissimi Galliarum et Poloniae regis, Ad Poloniae et Lythuaniae ordines epistola, Paris 1574, w zbiorach BN, Sygn. SD XVI.Qu.381.

Zdjęcie: A. Romulewicz

szość zachowanych ksiąg posiada oznaczenia w postaci pieczęci heraldycznej rodu Tyszkiewiczów lub ekslibris „Z biblioteki Hr. Tyszkiewiczów z Czerwonego Dworu" (stosowany przez B.J. i R. Tyszkiewiczów). Kolekcja składa się głównie ze starych druków w języku łacińskim, rzadziej - w niemieckim i polskim. Wiele z egzemplarzy szesnastowiecznych zostało wydanych w Krakowie. Księgozbiór nie jest tematycznie jednorodny. Tworzące go woluminy najczęściej dotyczą historii, polityki, teologii, filozofii i literatu-

\footnotetext{
35 Stare druki, [online] <http://www.bn.org.pl/zbiory/stare-druki> (21.12.2016).

36 Biblioteka Narodowa w latach 1945-1956..., s. 60.
} 


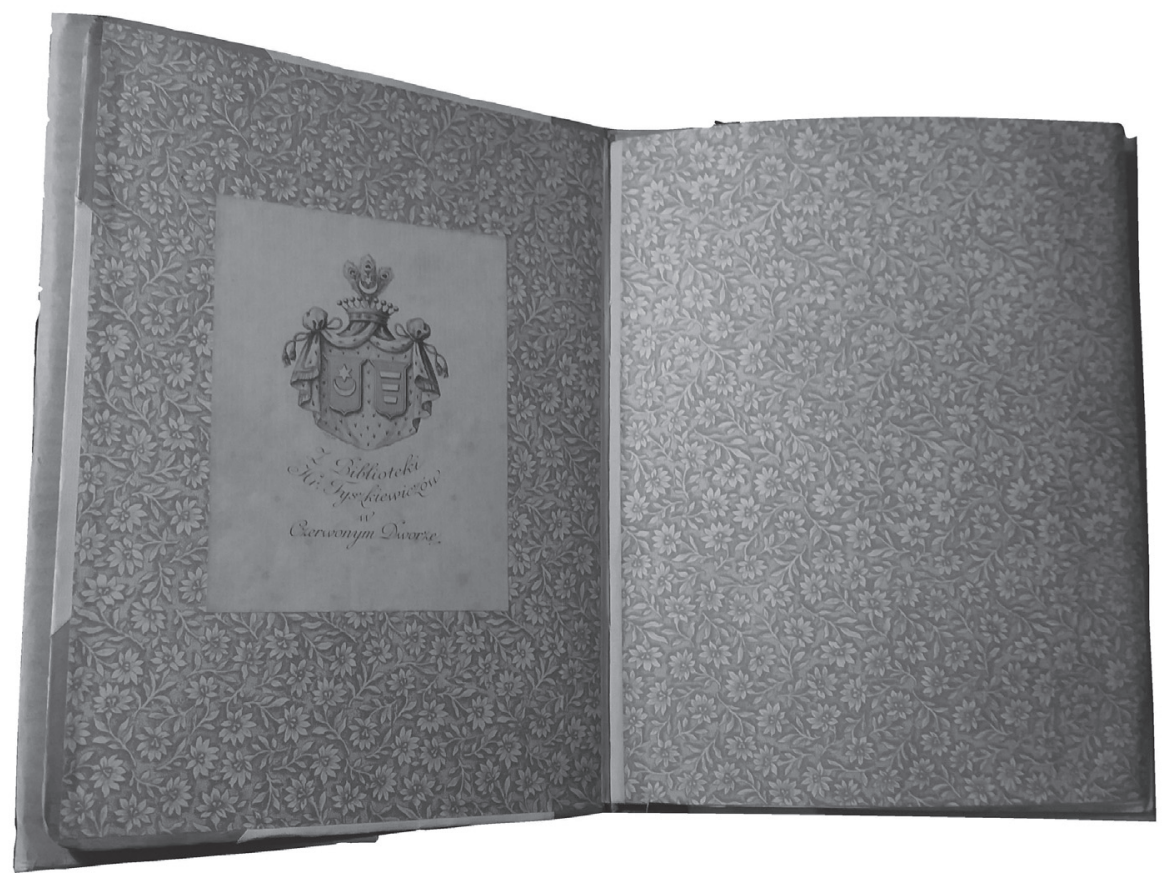

Fot. 5. Ekslibris rodu Tyszkiewiczów z Czerwonego Dworu. Źródło: [Statuta Vilnen. diocesis. sinodaliter per ... Joannem ex ducibus Lithuaniae ... episcopum Vilnen. cum suo capitulo de totius cleri eiusdem diocesis pro sinodo diocesana congregati consensu ac voluntate edita ... atque approbata], Kraków 1528, w zbiorach BN, Sygn. XVI Qu 473.

Zdjęcie: A. Romulewicz

ry. Najstarsze z druków to m.in. dzieła Erazma z Rotterdamu, Jana Długosza, Stanisława Hozjusza, Stanisława Grodzickiego, Bartłomieja Groickiego, Jana Herburta, Jana Kochanowskiego, Marcina Kromera, Jana Łaskiego, Stanisława Orzechowskiego, Piotra Skargi, Stanisława Sokołowskiego, Krzysztofa Warszewickiego. Kolekcja znajduje się obecnie w Zakładzie Starych Druków Biblioteki Narodowej w Warszawie, gdzie otoczona jest należytą opieką. Jak pokazały badania $\mathrm{z}$ autopsji oraz liczne zapiski na kartach katalogowych, wiele z egzemplarzy posiada defekty, m.in. brak lub uszkodzenia kart tytułowych, początkowych lub końcowych części dziel, wycięte dedykacje ${ }^{37}$. Kilka z dzieł to obiekty unikatowe w skali europejskiej ${ }^{38}$. W związku z tym druki najcen-

37 Informacje na temat różnych typów uszkodzeń dot. m.in. egzemplarzy o sygn.: BN XVI F 105, BN XVI F 109, BN XVI Qu 358, BN XVI Qu 366, BN XVI Qu 375, BN XVI Qu 447, BN XVI Qu 465, BN XVI Qu 466, BN XVI O 339.

38 Np. P. Caterla, Chorus Musarum in honorem, 1599, sygn. BN XVI Qu 467; B. Mandino, Oratio da foedere cum Christianis contra Turcam..., 1596, sygn. BN XVI Qu 433. 
niejsze i najbardziej narażone na zniszczenie udostępnia się wyłącznie w postaci mikrofilmów.

Na przełomie 2013 i 2014 r. przeprowadzono badania służące zebraniu informacji na temat występowania pozostałych książek z biblioteki w Czerwonym Dworze na terenie Polski. Kwerenda skierowana do kilkudziesięciu krajowych bibliotek publicznych i naukowych, instytutów badawczych i innych ośrodków gromadzących zbiory zabytkowe pozwoliła ustalić, że poza Warszawą pojawiają się nieliczne, rozproszone egzemplarze. Większość z nich zidentyfikowana i zweryfikowana została poprzez znaki proweniencyjne: pieczęcie i ekslibrisy. Co ważne, na kwerendę przeprowadzoną przez WBP w Olsztynie odpowiedziały także instytucje, które dotychczas nie zarejestrowały pozycji z biblioteki czerwonodworskiej (zaznaczając, że prace nad rejestrami proweniencji starych druków nadal trwają lub są dopiero planowane). Nie wyklucza to więc odnalezienia w przyszłości kolejnych egzemplarzy z zabytkowej kolekcji Tyszkiewiczów. Nadesłane informacje pozwoliły natomiast ustalić, że rozproszone druki znajdują się w:

- Instytucie Badań Literackich Polskiej Akademii Nauk w Warszawie - dwa egzemplarze z XVIII w.;

- Wojewódzkiej i Miejskiej Bibliotece Publicznej im. Cypriana Norwida w Zielonej Górze - jeden egzemplarz z 1528 r.;

- Bibliotece Kórnickiej Polskiej Akademii Nauk - jeden egzemplarz z 1695 r., oznaczony pieczęcią: „Biblioteka Czerwonodworska. Z duplikatów”;

- Bibliotece Jagiellońskiej w Krakowie (Oddział Zbiorów Specjalnych, Sekcja Starych Druków) - dziesięć egzemplarzy (jeden piętnastowieczny: Tractatus de duabus Sarmatijs Asiana, et Europiana ... Macieja z Miechowa, trzy siedemnastowieczne, siedem osiemnastowiecznych);

- Bibliotece Publicznej miasta stołecznego Warszawy - jeden egzemplarz z 1661 r. w oprawie dziewiętnastowiecznej ${ }^{39}$, zakupiony do biblioteki w $1961 \mathrm{r}$;

- Bibliotece Śląskiej w Katowicach - 11 egzemplarzy (z XVI w. - sześć egzemplarzy, z XVII w. - cztery, z XVIII w. - jeden), wszystkie opatrzone pieczęcią wskazującą na kolekcję Tyszkiewiczów z Czerwonego Dworu.

Negatywnie na kwerendę odpowiedziało 25 instytucji, w tym 11 bibliotek uczelni wyższych, dziesięć publicznych, jedna pedagogiczna oraz trzy placówki badawcze.

${ }^{39}$ Stary druk opatrzony pieczęcią „Z duplikatów Biblioteki Czerwonodworskiej”. Biblioteka Publiczna nie posiada rękopisów i archiwaliów z Czerwonego Dworu - zob. Katalog starych druków Biblioteki Publicznej m.st. Warszawy, cz. 3: Polonica XVII wieku, oprac. J. Rudnicka, przy współudz. J. Górki i K. Sokołowskiej-Grzeszczykowej, Warszawa 1976, s. 205, poz. 1007; potwierdzone przez pismo SD.8/1/2014 z dnia 32 stycznia 2014 r. Biblioteki Publicznej m.st. Warszawy do Wojewódzkiej Biblioteki Publicznej w Olsztynie. 
W Bibliotece Narodowej w Zakładzie Starych Druków (poza wspominanym wcześniej oryginalnym katalogiem) znajdują się także Materiaty rejestracyjne do centralnego katalogu poloników w Bibliotece Narodowej $w$ Warszawie $^{40}$. Zeszyt z numerem 1, obejmujący 93 karty, zawiera opisy Starych druków Biblioteki Tyszkiewiczów z Czerwonego Dworu (Sucha) łącznie 243 pozycje. Znajdują się w nim noty dotyczące zbiorów piętnastoi szesnastowiecznych. Przy poszczególnych pozycjach dodane zostały aktualne sygnatury Biblioteki Jagiellońskiej. Dokument stanowi rejestr starych druków wykonany przez Alodię Kawecką-Gryczową w dniach 25 III, 1 VI, 22 X 1948 i 22 I 1949 r.

Materiały mówiące o rejestracji starych druków z Czerwonego Dworu z XVII i XVIII w. w centralnym katalogu poloników Biblioteki Narodowej zawarto w pięciu kolejnych zeszytach. Spis wykonała Anna Kamińska w 1948 r. (zeszyty 1 i 2 - XVII w., zeszyt 3 - XVII/XVIII w., zeszyty 4 i 5 - XVIII w.). W trzech ostatnich zeszytach - w zbiorach osiemnastowiecznych - dominują proweniencje Michała Pełki Polińskiego, profesora matematyki Uniwersytetu Wileńskiego. W tej dokumentacji zanotowano łącznie 998 pozycji siedemnastowiecznych oraz 570 osiemnastowiecznych.

Do 2011 r. w Zakładzie Starych Druków Biblioteki Narodowej przechowywany był także komplet inwentarzy poloników siedemnasto- i osiemnastowiecznych z biblioteki Tyszkiewiczów z Czerwonego Dworu - stan na 1951 r., sprawdzony w 1960 r. (trzy teczki). Obecnie w Zakładzie Starych Druków znajduje się tylko inwentarz poloników osiemnastowiecznych (teczka 2 i 3). Teczka pierwsza z opisami druków siedemnastowiecznych została zagubiona ${ }^{41}$.

Ponad 900 pozycji z notami własnościowymi B.J. Tyszkiewicza oraz Róży z Branickich wykazuje część trzecia Bibliografii polskiej Karola i Stanisława Estreicherów, wydawana w Krakowie od $1906 \mathrm{r}^{42}$ Obejmuje ona druki od XV do XVIII w. „,W układzie abecadłowym”, a kolejnych 190 tytułów odnaleźć można w wydaniu scalonym tejże bibliografii z roku $1999^{43}$. Wiele informacji o nowych nabytkach do biblioteki w Czerwonym Dworze trafiło do Bibliografii polskiej z pierwszej ręki. Wielokrotnie to sami właściciele przesyłali do Estreicherów opisy bibliograficzne ksiąg. Niemniej bibliografia ta nie stanowi dzisiaj kompletnego źródła informacji, podobnie jak wspominane wcześniej rejestry czy kartoteki. Najbogatszy zbiór pochodzą-

40 Zob. Katalog starych druków Biblioteki Publicznej..., s. 149, poz. 388a i 388b.

41 Informacja o spisach bez sygnatury (kopie maszynopisów) za: tamże, s. 149, poz. 389.

42 Zob. K. Estreicher, S. Estreicher, Bibliografia polska, cz. 3: Obejmujaca druki XV-XVIII w. w układzie abecadlowym, t. 21-26, Kraków 1906-1915; t. 27 (1929); t. 30-33 (1934-1939); t. 34, z. 1 (1951); t. 34, z. 2 (2000) - zob. tamże, s. 149, poz. 390.

43 Zob. Bibliografia polska Karola i Stanistawa Estreicherów. Dopetnienia i sprostowania do części 3, z. 1: A-G, red. t. S. Siess-Krzyszkowski, Kraków 1999. 
cy z Czerwonego Dworu zarejestrowany jest tylko częściowo w katalogach Biblioteki Narodowej w Warszawie i wymaga dalszych prac z uwzględnieniem znaków proweniencyjnych.

\section{Streszczenie}

Część biblioteki Benedykta Tyszkiewicza z Czerwonego Dworu opuściła rodową siedzibę na początku XX w. Kilka tysięcy starych druków, głównie z XVI i XVII w., w 1918 r. znalazło się w Suchej, na dworze Branickich i Tarnowskich. Podczas II wojny światowej kolekcja została rozproszona. W pierwszych latach powojennych ocalały zbiór został podzielony pomiędzy biblioteki w kraju, m.in. w Krakowie i Wrocławiu. Ostatecznie biblioteka Tyszkiewiczów trafiła do Biblioteki Narodowej w Warszawie, gdzie stanowi obecnie kolekcję składającą się z około 3500 starych druków. Ponadto $\mathrm{w}$ Bibliotece Narodowej w Warszawie przechowywanych jest kilka rękopisów z archiwum Czerwonego Dworu. Wszystkie dokumenty pochodzą z zakupów na aukcji antyków. Większość zachowanych ksiąg oznaczona jest pieczęcią heraldyczną Tyszkiewiczów lub ekslibrisem Benedykta Jana Tyszkiewicza. Kolekcja składa się przede wszystkim ze starych druków wydanych po łacinie, rzadziej w języku niemieckim i polskim. Wiele książek z XVI w. zostało opublikowanych w Krakowie. Tematycznie nie są one jednorodne i najczęściej dotyczą historii, polityki, teologii, filozofii i literatury. W 2014 r. WBP w Olsztynie podjęła kwerendę, w wyniku której uzyskano informacje na temat książek z biblioteki z Czerwonego Dworu rozproszonych $\mathrm{w}$ różnych miejscach na terenie Polski (woluminy z kolekcji znajdują się m.in. w Bibliotece Śląskiej w Katowicach).

Słowa kluczowe: Benedykt Jan Tyszkiewicz (1875-1948) - Czerwony Dwór (Litwa) - biblioteki prywatne - archiwa prywatne - zbiory biblioteczne - stare druki.

Summary

\section{The Polish History of the Library of Tyszkiewicz Family}

Part of the library of Benedict John Tyszkiewicz from Czerwony Dwór left the ancestral seat at the beginning of the twentieth century. In 1918 a few thousand early printed books, mainly the ones from sixteenth and seventeenth centuries, were stored in Sucha, in the manor house of the Branic- 
ki and Tarnowski families. During World War II, the collection was dispersed. In the 40's of the twentieth century, part of it went to Krakow. Rest of the collection was divided among the other libraries in Poland, books mostly went to the Ossolineum collection in Wroclaw.

Eventually Tyszkiewicz collection has been moved to the National Library in Warsaw. Currently, the collection consists of app. 3500 early printed books. In 2014 we made a query and gathered information on the presence of books from the discussed library in the Czerwony Dwór which are now kept in Poland. Apart from Warsaw, books are dispersed in several other institutions, for example in the Library of Silesia in Katowice. A few handwritten documents from the archives of the Czerwony Dwór are stored in the National Library in Warsaw. All documents were purchased at the antique auctions. Most of the surviving books are marked with a heraldic stamp of Tyszkiewicz family or ex-libris by B. J. Tyszkiewicz. The collection consists mainly of early printed books published in Latin, more rarely in German and Polish. Many of the books from the sixteenth century had been published in Krakow. These books are not thematically homogeneous. Mostly they concern the history, politics, theology, philosophy and literature.

Key words: Tyszkiewicz, Benedykt Jan (1875-1948) - Raudon dvaris (Lithuania) - private libraries - private archives - library collections - old prints. 